\title{
Should emergency contraception be a general sales medicine?
}

\author{
Eliza Morgan, Siti Amirah Binte Mohd Amin, Kearsey Elise, \\ Sophie Butcher
}

University of Edinburgh, Edinburgh, UK

\section{Correspondence to} Sophie Butcher, Old College, South Bridge, CERT, Edinburgh, UK; Secretary.CERT@

buchananinst.org

Received 8 September 2020 Revised 24 November 2020 Accepted 25 November 2020 Published Online First 16 April 2021

\section{Check for updates}

(C) Author(s) (or their employer(s)) 2021. No commercial re-use. See rights and permissions. Published by BMJ.

To cite: Morgan $E_{1}$ Amirah Binte Mohd Amin S, Elise K, et al. BMJ Sex Reprod Health 2021;47:67-68.
Before the coronavirus (COVID-19) pandemic, it was standard procedure in the UK that access to emergency contraception (EC) was mainly limited to faceto-face consultations with a pharmacist, a prescription from a general practitioner (GP) or family planning clinic, or overthe-counter purchases. While moves towards accessibility have been made in recent years, with the inclusion of remote consultations and collections or postage of EC, greater measures need to be taken to open up further routes of accessibility, especially in the era of social distancing.

During the height of the first 2020 UK lockdown, the National Heath Service (NHS) advised people to avoid face-to-face GP appointments unless absolutely necessary. A British Association for Sexual Health and HIV (BASHH) survey found that since March 2020, 54\% of local sexual and reproductive health (SRH) clinics have closed altogether. ${ }^{1}$ BASHH also noted that staffing at SRH clinics is now less than half of what it was at the beginning of March. Thus, EC has become increasingly inaccessible at both SRH clinics and GP surgeries. As a result, many organisations such as the British Pregnancy Advisory Service (BPAS) have advocated for EC to become a general sales medicine, which would allow it to be sold straight off the shelf, removing the need for compulsory consultations. ${ }^{2}$ With the current staff shortages, and with pharmacies becoming increasingly stretched, it makes sense to expand access to EC so that women can purchase it off the shelf rather than from behind the counter. This is especially important as EC is a time-sensitive medication that needs to be taken as soon as possible.

Some people have criticised plans to make EC available as a general sales medicine, as by keeping it under a prescription it can be used as a form of safeguarding to ensure the welfare of vulnerable individuals. Evidence suggests that victims of domestic violence and abuse are twice as likely to use EC than other women, due to the higher chance that their partners have raped them or pressured them into having unprotected sex. ${ }^{3}$ Thus, healthcare services are a critical point of contact for many abuse victims and survivors, and as pharmacists dispense $50 \%$ of all EC, this is an important opportunity for safeguarding. ${ }^{4}$ Despite this, pharmacists are not currently a part of the Identification and Referral to Improve Safety (IRIS) programme in the UK, which provides training to staff on how to identify domestic violence and abuse and how to refer vulnerable individuals onto the relevant specialist services. ${ }^{5}$ When pharmacists conduct a consultation, no questions are targeted towards domestic abuse, and pharmacists are unlikely to provide access to specialist support. This lack of safeguarding calls into question the true benefits of mandatory pharmacy consultations.

A further argument as to why pharmacy consultations may be necessary in the transaction of EC is that a pharmacist or other knowledgeable healthcare provider can help educate women to make the right choice for themselves. With three different types of EC available (Levonelle, ellaOne, intrauterine devices), a pharmacist can assist in making the best decision for an individual. But despite this, a BPAS study that conducted a mystery shopping exercise in 30 UK pharmacies found that only a small percentage of pharmacies provided information on the most effective forms of EC. ${ }^{6}$ Similarly, no pharmacy offered information about ongoing forms of contraception for future use, and neither did they recommend any services that could do so, once again calling into question the benefit of mandatory consultations.

As a form of medication EC is extremely safe, and even more so than many medications that can currently be bought off the shelf. The World Health Organization (WHO) has claimed that side effects of EC are uncommon, with no threat to future 
fertility, and has placed no restrictions on the medical eligibility of those women who can use EC. ${ }^{7}$ Moreover, as the UK has the highest teenage pregnancy rate in Western Europe, and one in six pregnancies in the UK are unintended, ${ }^{8}$ EC should be actively encouraged as a backup option to many women. It is clear that the health consequences of an unintended pregnancy are much higher than those posed by the use of EC, ${ }^{9}$ therefore it would seem to be more beneficial to women to be able to purchase EC directly off the shelf rather than from behind the counter.

The Royal College of Obstetricians and Gynaecologists (RCOG) has found that the current consultation process can be a barrier to access, with many women feeling "uncomfortable, embarrassed, or judged". ${ }^{10}$ This is especially true as the BPAS study found that many consultations take place at the pharmacy counter, rather than in a private room, making it a lot less likely that many women would feel comfortable voicing any issues or queries. ${ }^{11}$ A 2014 study published in the European Journal of Contraception and Reproductive Health found that $11 \%$ of women in the UK had refrained from using EC in the past due to being "embarrassed to ask for it". ${ }^{12}$ This was in comparison to $6 \%$ in other European countries where a consultation is not necessary. Thus, a move towards EC as a general sales medicine in the UK would hopefully protect more women from unwanted pregnancy.

Despite many people arguing that compulsory consultations for EC can provide forms of safeguarding and advice on the best forms of EC for an individual, it is questionable how successful this is in practice. In reality, the safety of EC should allow for further routes to access it, such as off the shelf as a general sales medicine. This is particularly apposite with the recent cuts in healthcare services during the coronavirus pandemic. Moreover, women's own experiences of viewing compulsory consultations as a barrier to access due to judgement and embarrassment should also be considered. Women are more than capable of making their own health decisions, and with a historical precedent of women's own views being overlooked in the medical sphere, this needs to be addressed and overturned to ensure women can voice their opinions.

Correction notice This article has been updated since it was published online. Elise Kearsey has been added to the author list.

Contributors All the contributors to this article are members of CERT (Contraception Education Reform Team) Scotland: EM (Biomedical Team Leader), SABMA (Stigma Team Leader) and SB (President). EM led the write-up of this article, SA was the coordinator of the original piece of research that examined access to emergency contraception during COVID-19 on which this article was based, while SB was responsible for the overall coordination of the work. All three contributors are students at the University of Edinburgh, with EM and SB studying Sociology and Politics, and SABMA studying Comparative Public Policy.
Funding The authors have not declared a specific grant for this research from any funding agency in the public, commercial or not-for-profit sectors.

Competing interests None declared.

Patient and public involvement Patients and/or the public were not involved in the design, or conduct, or reporting, or dissemination plans of this research.

Patient consent for publication Not required.

Provenance and peer review Not commissioned; externally peer reviewed.

ORCID iD

Sophie Butcher http://orcid.org/0000-0003-2776-6148

\section{REFERENCES}

1 British Association for Sexual Health and HIV. BASHH COVID-19 sexual health 'clinical thermometer' survey initial results snapshot, 2020. Available: https:/members.bashh.org/ Documents/COVID-19/BASHH\%20COVID-19\%20Clinical\% 20Thermometer\%20Survey\%20-\%20First\%20Round\% 20Results\%20Snapshot\%20.pdf

2 British Pregnancy Advisory Service. Emergency contraception needs urgent review, 2016. Available: < https://www.bpas. org/about-our-charity/press-office/press-releases/emergencycontraception-needs-urgent-review/> [Accessed 1 Aug 2020].

3 National Institute for Health Research. Could requesting emergency contraception be a sign of domestic violence and abuse? Available: https://arc-w.nihr.ac.uk/research/ projects/including-community-pharmacies-responses-womenexperience-domestic-violence-abuse/

4 MedicalXPress. Requests for emergency contraception could be an important sign of abuse, 2018. Available: https:// medicalxpress.com/news/2018-12-emergency-contraceptionimportant-abuse.html

5 National Institute for Health Research Applied Research Collaboration West. Could requesting emergency contraception be a sign of domestic violence and abuse? Available: https://arc-w.nihr.ac.uk/research/projects/includingcommunity-pharmacies-responses-women-experiencedomestic-violence-abuse/

6 British Pregnancy Advisory Service. Pharmacy provision of emergency contraception: a mystery shopper study, 2018. Available: https://www.bpas.org/media/3073/ec-report-1.pdf

7 World Health Organization. Emergency contraception, 2018. Available: https://www.who.int/news-room/fact-sheets/detail/ emergency-contraception [Accessed 6 Oct 2020].

8 Population Matters. Teenage pregnancy. Available: https:// populationmatters.org/sites/default/files/teenage_pregnancy.pdf

9 Norris Turner A, Ellertson C. How safe is emergency contraception? Drug Saf 2002;25:695-706.

10 Royal College of Obstetricians and Gynaecologists. Better for women: improving the health and wellbeing of girls and women, 2019. Available: https://www.rcog.org.uk/globalassets/ documents/news/campaigns-and-opinions/better-for-women/ better-for-women-full-report.pdf

11 Murphy C, Pooke V. Emergency contraception in the UK: stigma as a key ingredient of a fundamental women's healthcare product. Sex Reprod Health Matters 2019;27:1225.

12 Nappi RE, Lobo Abascal P, Mansour D, et al. Use of and attitudes towards emergency contraception: a survey of women in five European countries. Eur J Contracept Reprod Health Care 2014;19:93-101. 


\section{Correction: Should emergency contraception be a general sales medicine?}

Morgan E, Amirah Binte Mohd Amin S, Kearsey E, et al. Should emergency contraception be a general sales medicine? BMJ Sex Reprod Health 2021;47:67-8. doi: 10.1136/ bmjsrh-2020-200872.

The third author's name was transposed. Her correct name is Elise Kearsey.

(C) Author(s) (or their employer(s)) 2021. No commercial re-use. See rights and permissions. Published by BMJ.

BMJ Sex Reprod Health 2021;47:e13. doi:10.1136/bmjsrh-2020-200872corr1

(D) Check for updates 